\title{
PERANAN CORPORATE PUBLIC RELATIONS (CPR) DAN MARKETING PUBLIC RELATIONS (MPR) DALAM MENINGKATKAN CITRA PERUSAHAAN
}

\author{
Irien Violinda Anggriani \\ Fakultas Ekonomi dan Ilmu Sosial UIN Sultan Syarif Kasim Riau \\ email: irien.violinda.anggriani.uin-suska.ac.id \\ violindairien@yahoo.com
}

\begin{abstract}
Abstrak
Komunikasi tidak secara langsung menimbulkan perilaku tertentu, tetapi cenderung mempengaruhi cara kita mengorganisasikan citra kita tentang lingkungan. Public Relations digambarkan sebagai input-output, proses intern dalam model ini adalah pembentukan citra, sedangkan input adalah stimulus yang diberikan dan output adalah tanggapan atau perilaku tertentu. Konsep Corporate Public Relations (CPR) merupakan konsep Public Relations (PR) dalam suatu organisasi namun, seiring dengan perkembangan baru sosialisasi PR dan pemasaran, PR kemudian ditempatkan dibagian Marketing, sedangkan CPR masuk kedalam bagian perusahaan secara umum. Fungsi dan peran CPR dan Marketing Public Relations (MPR) jelas berbeda dan memiliki tujuan tidak hanya sekedar untuk meningkatkan penjualan semata tetapi lebih jauh dari itu yakni berusaha memberikan gambaran yang utuh tentang produk maupun corporate kepada stakeholder-nya, sehingga mampu memberikan image yang positif mengenai produk maupun perusahaan.
\end{abstract}

\section{PENDAHULUAN}

Menghadapi tren global dan resistensi masyarakat sekitar perusahaan, maka sudah saatnya setiap perusahaan memandang serius pengaruh ekonomi, lingkungan dan dimensi sosial dari setiap aktivitas bisnisnya, serta berusaha membuat laporan setiap tahunnya kepada stakeholders masing-masing. Laporan bersifat non finansial yang dapat digunakan sebagai acuan oleh perusahaan dalam melihat ekonomi dan lingkungannya serta dimensi sosial.

Perkembangan dunia bisnis secara global diikuti oleh peningkatan kesadaran publik akan tanggungjawab perusahaan, terutama dalam 40 tahun terakhir. Indikator keberhasilan perusahaan dalam memenangkan persaingan di dalam dunia bisnis adalah profit dan pertumbuhan. Perusahaan tidak hanya bertujuan mencapai profit dan pertumbuhan, tetapi juga keberlangsungan dimana untuk mencapainya, perusahaan dituntut untuk menunjukkan rasa tanggungjawab dan kepedulian terhadap isu-isu sosial baik didalam perusahaan maupun yang berkembang didalam masyarakat. Untuk mencapai keberlangsungan (sustainability), lahirlah konsep yang dikenal sebagai Corporate Social Responsibility (CSR). Dimana CSR merupakan suatu konsep terintegrasi 
yang menggabungkan aspek bisnis dan sosial dengan selaras agar perusahaan dapat membantu tercapainya kesejahteraan stakeholders, serta dapat mencapai profit yang maksimum yang dapat meningkatkan harga saham. Konsep Corporate Public Relations (CPR) merupakan konsep Public Relations (PR) dalam suatu organisasi namun, seiring dengan perkembangan baru sosialisasi PR dan pemasaran, PR kemudian ditempatkan dibagian Marketing, sedangkan CPR masuk kedalam bagian perusahaan secara umum. Fungsi dan peran CPR dan Marketing Public Relations (MPR) jelas berbeda, hal ini dikemukakan oleh Grunig (1989).

\section{ISI}

\section{a. Tujuan penulisan}

Tujuan penulisan makalah ini adalah sebagai berikut:

1. Menjelaskan peranan penting Corporate Public Relations (CPR).

2. Menjelaskan peranan penting Marketing Public Relations (MPR).

3. Menjelaskan perbedaan antara Corporate Public Relations (CPR) dan Marketing Public Relations (MPR) untuk meningkatkan Citra Perusahaan.

\section{b. Manfaat Penulisan}

Penulisan makalah ini

diharapkan bermanfaat untuk:

1. Untuk mengetahui komponenkomponen dasar PR sebuah perusahaan.

2. Sebagai aplikasi koordinasi secara terencana atas unsur-unsur ekonomi, psikologi, politik dan keterampilan PR dalam memperoleh simpati (kerjasama) dari pihak-pihak terkait agar dapat beroperasi atau masuk kepasar tertentu demi peningkatan citra perusahaan.

\section{c. Kerangka Teoritis}

Public Relations (PR) dalam suatu organisasi seringkali disebut sebagai Corporate Public Relations (CPR). Seiring dengan perkembangan baru dari sosialisasi atau kampanye PR dan pemasaran, PR kemudian ditempatkan dibagian Marketing. Fungsi dan peran Corporate Public Relations (CPR) dan Marketing Public Relations (MPR) berbeda.

A. Corporate Public Relations (CPR). Public Relations (PR) yang di Indonesia disebut sebagai Hubungan Masyarakat (Humas) adalah sesuatu yang merangkum keseluruhan komunikasi yang terencana, baik itu ke dalam maupun ke luar, antara suatu organisasi (lembaga) dengan semua khalayaknya dalam rangka mencapai tujuan-tujuan spesifik yang berlandaskan pada saling pengertian.

Dari definisi ini setidaknya dapat dijelaskan bahwa PR adalah kegiatan komunikasi dua arah yang dilakukan lembaga atau instansi kepada publiknya dengan maksud adanya saling pengertian. Komunikasi ini harus direncanakan karena menyangkut tujuan-tujuan lembaga.

Rhenald Khasali dalam

bukunya "Manajemen Public Relations" (2005), mengatakan, CPR mempunyai tugas yang sangat sensitif, yakni menjaga kepuasan para stakeholders termasuk pemegang saham dan pemerintah. CPR bertanggung jawab terhadap pencegahan dan pemecahan krisis yang dapat mematikan perusahaan. Pekerjaan-pekerjaan ini membutuhkan kedekatan CPR dengan pemimpin puncak dan memerlukan dukungan penuh dari pimpinan puncak atau di 
Indonesia dalam hal ini adalah pemegang saham mayoritas.

Perusahaan-perusahaan besar yang mempunyai anak perusahaan dalam jumlah besar, karyawan yang sangat banyak, kerjasama usaha yang terkait secara nasional maupun internasional dengan badan-badan lain dan mempunyai banyak unsur lingkungan yang perlu didekati, maka tugas CPR dapat dibagi-bagi lebih detil lagi. Misalnya, hubungan dengan komunitas, pers dan pemerintah.

\section{Ruang lingkup pekerjaan CPR, antara lain:}

a. Hubungan dengan pemerintah: lobi, mempercepat proses prosedur perizinan, memperoleh dukungandukungan moril, dan izin-izin legal lainnya

b. Hubungan dengan

komunitas: masalah

polusi, keamanan, fasilitas-fasilitas sosial, keterlibatan komunitas, menjadi warga kota (negara) yang baik

c. Hubungan dengan media: press release, press conference, media tour, interview, jurnalisme foto

d. Hubungan dengan karyawan: moral kerja, citra karyawan, budaya perusahaan, filosofi perusahaan, media internal, dukungan karyawan atas produk-produk perusahaan, kegiatan-kegiatan karyawan.

e. Hubungan dengan pemegang saham

f. Hubungan dengan bank.

g. Hubungan dengan pemimpinpemimpin opini.

h. Hubungan dengan akademisi.

i. Mengatasi krisis: perusahaan menurun, krisis yang meluas.

\section{B. Marketing Public Relations (MPR). \\ Menurut Harris (1994),} marketing public relations merupakan proses perencanaan, pelaksanaan dan pengevaluasian program-program yang merangsang pembelian dan kepuasan konsumen melalui komunikasi yang dapat dipercaya dan melalui kesankesan yang menghubungkan perusahaan dan produknya sesuai dengan kebutuhan keinginan, perhatian dan kepentingan para konsumen. Jika manajer pemasaran lebih berorientasi pada bottom-line, maka MPR lebih ke mempersiapkan dan menyampaikan komunikasi yang unggul. Sebuah perusahaan menerapkan Marketing Public Relations untuk mendukung perusahaan atau promosi produk dan penciptaan image. Secara struktural, MPR adalah bekerja untuk mendukung keberadaan bagian pemasaran. Adapun tujuan dari Marketing Public Relations menurut Kotler (1995) adalah sebagai berikut:

1. Membangun kesadaran konsumen. Dengan Marketing Public Relations dapat menempatkan cerita dimedai masa untuk membawa perhatian pada suatu produk, jasa, orang, organisasi atau ide.

2. Membangun kredibilitas, dengan Marketing Public Relations dapat menambah kredibilitas dengan mengkomunikasikan pesan dalam suatu konteks editorial.

3. Mendorong tenaga penjual dan penyalur. Dengan Marketing Public Relations dapat mendorong antusiasme tenaga penjual dan penyalur.

4. Mengurangi biaya promosi, Marketing Public Relations memerlukan sedikit biaya 
dibandingkan pos langsung dan media iklan. Semakin kecil anggaran promosi penjualan maka semakin kuat alasan menggunakan Marketing Public Relationss untuk memperoleh perhatian.

\section{Perbedaan fungsi dan peran Corporate Public Relations (CPR) dan Marketing Public Relations (MPR)}

\section{(CPR)}

\section{Fungsi Corporate Public Relations}

1. Membangun dan mempertahankan hubungan yang baik dan saling bermanfaat.

2. Melakukan perencanaan dan menopang program pengembangan citra sebagai bagian manajemen organisasi.

3. Menangani kegiatan-kegiatan menjembatani hubungan komunikasi antara organisasi dengan publiknya.

4. Memonitor kesadaran, pendapat, sikap dan perilaku di dalam dan di luar organisasi yang terkait dengan citra organisasi.

5. Menganalisa dampak komunikasi dari kebijakan, prosedur, dan tindakan-tindakan yang ditujukan kepada publik.

6. Menyesuaikan kebijakan, prosedur, dan tindakan-tindakan yang ternyata menimbulkan masalah komunikasi dan bertentangan dengan kepentingan publik dan kelangsungan hidup organisasi.

7. Memberikan jasa konsultan kepada manajemen untuk menyusun kebijakan, prosedur, dan tindakantindakan baru yang saling menguntungkan bagi pembentukan iklim komunikasi baik pada organisasi maupun publiknya.

8. Menstimulir kearah komunikasi konvergen dan sinergi dua arah antara organisasi dengan publiknya, serta menjaga dan melestarikannya.

9. Memperkenalkan perubahanperubahan spesifik dalam kesadaran, pendapat, sikap dan perilaku di dalam dan di luar organisasi,terjaganya hubungan atau menghasilkan hubungan baru antara organisasi dengan publiknya.

10. Membangun dan mempertahankan hubungan yang baik dan saling bermanfaat antara manajer dan karyawan tempat organisasi menggantungkan kesuksesannya.

11. Menasehati para eksekutif mengenai cara- cara menangani pendapat umum.

12. Menggunakan komunikasi untuk mempengaruhi pendapat umum

13. Membantu menegakkan dan memelihara aturan bersama dalam komunikasi, demi terciptanya saling pengertian dan kerjasama antara lembaga/ perusahaan dengan publiknya.

14. Membantu manajemen dan menanggapi pendapat publiknya, membantu manajemen dan menanggapi pendapat publiknya.

15. Mengatur dan menekankan tanggungjawab manajemen dalam melayani kepentingan masyarakat.

16. Membantu manajemen dalam mengikuti, memonitor, bertindak sebagai suatu sistem tanda bahaya untuk membantu manajemen berjaga-jaga dalam menghadapi berbagai kemungkinan buruk. 
17. Menggunakan penelitian dan teknik-teknik komunikasi yang efektif dan persuasif untuk mencapai semua itu.

18. Penciptaan dampak yang menyenangkan pada publiknya atas kebijaksanaan dan operasionalisasinya oleh pimpinan lembaga. Tentu saja bagi lembaga, dampak yang diinginkan adalah dampak yang dapat menguatkan citra positifnya dari sudut pandang publik.

Sedangkan Peran Corporate Public Relations (CPR)

1. Membangun Citra Perusahaan Melalui Program CSR

2. Menerapkan CSR yang Lebih Strategis

3. Membangun kerjasama antar stakeholders yang difasilitasi perusahaan tersebut dengan menyusun program-program pengembangan masyarakat sekitarnya.

4. Membangun kerjasama antar stakeholders yang difasilitasi perusahaan tersebut dengan menyusun program-program pengembangan masyarakat sekitarnya.

5. Menghadapi tren global dan resistensi masyarakat sekitar perusahaan, maka sudah saatnya setiap perusahaan memandang serius pengaruh dimensi sosial, ekonomi dan lingkungan dari setiap aktivitas bisnisnya.

6. Berusaha membuat laporan setiap tahunnya kepada stakeholders-nya.

7. Menyediakan saran kepada Manajemen yang berhubungan dengan kebijakan, hubungan dan komunikasi.
8. Membangun salingpengertian atau Mempengaruhi dan meyakinkan publik.

9. Bekerja sama dengan pihak media untuk mencari publisitas atau merespon ketertarikan mereka terhadap lembaga.

10. Memberikan respon terhadap suatu masalah, menginformasikan, dan memotivasi karyawan lembaga.

11. Membantu lembaga beradaptasi dengan harapan publik, dan menjelaskan aktivitas lembaga mereka.

12. Berhubungan langsung dengan lembaga-lembaga pemerintah lain yang terkait dengan kelangsungan lembaga kita. Melobi juga dapat menjadi salah satu program hubungan dengan lembaga pemerintah lain.

13. Mengidentifikasi dan mengetahui isu yang berkembang pada publik yang berakibat pada lembaga.

14. Menciptakan kebutuhan dan memberanikan publik untuk mendukung lembaga, terutama melalui kontribusi finansial.

15. Menciptakan dan menjaga kepercayaan investor dan membangun hubungan baik dengan komunitas finansial. Juga dikenal dengan Investor Relations atau Stakeholders Relations.

16. Berhubungan dengan lembagalembaga lain dalam industri dari sebuah organisasi dan dengan asosiasi dagang.

17. Berhubungan dengan individuindividu dan kelompok-kelompok dalam berbagai kelompok budaya.

18. Memancing ketertarikan seseorang terhadap lembaga dengan mengadakan 
suatu kegiatan yang didisain untuk dapat berinteraksi dengan mereka, sehingga mendapat perhatian yang lebih.

19. Kombinasi dari aktifitas yang didisain untuk menjual produk, jasa atau ide, termasuk iklan, Collateral Materials, publisitas, promosi, direct mail, dan pameran dagang.

20. Menasehati manajemen mengenai jalan dan cara menyusun kebijaksanaan dan operasionalisasi lembaga untuk dapat diterima secara maksimal oleh publik.

21. Merencanakan dan melaksanakan program-program yang dapat menimbulkan penafsiran yang menyenangkan terhadap kebijaksanaan dan operasionalisasi lembaga.

\section{Ruang lingkup pekerjaan} Corporate Public Relations (CPR), antara lain:

1. Hubungan dengan pemerintah: lobi, mempercepat proses prosedur perizinan, memperoleh dukungan-dukungan moril, dan izin-izin legal lainnya

2. Hubungan dengan komunitas: masalah polusi, keamanan, fasilitasfasilitas sosial, keterlibatan komunitas, menjadi warga kota/negara yang baik

3. Hubungan dengan media: press release, press conference, media tour, interview, jurnalisme foto

4. Hubungan dengan karyawan: moral kerja, citra karyawan, budaya perusahaan, filosofi perusahaan, media internal, dukungan karyawan atas produk-produk perusahaan, kegiatan-kegiatan karyawan.

5. Hubungan dengan pemegang saham

6. Hubungan dengan bank.

7. Hubungan dengan pemimpinpemimpin opini.

8. Hubungan dengan akademisi.

9. Mengatasi krisis: perusahaan menurun, krisis yang meluas.

Fungsi Marketing Public Relations (MPR)

1. Memposisikan perusahaan sebagai "leader" atau "expert"

2. Membangun kepercayaan (confidence and trust) konsumen 3. Memperkenalkan produk baru. 4. Menghapus, meluncurkan kembali (relaunch) produk-produk yang sudah dewasa (mature)

5. Mengkomunikasikan keuntungankeuntungan produk lama.

6. Mempromosikan cara-cara pemakaian baru atas produk yang sudah dikenal

7. Melibatkan, menggerakkan masyarakat terhadap produk kita

8. Menjangkau "secondary markets"

9. Menekankan pasar yang lemah 10. Memperluas jangkauan iklan 11. Menyebarkan berita sebelum beriklan 12. Membuat iklan lebih berbunyi (menjadi bahan pembicaraan) 13. Menjelaskan "product story"dengan lebih detail 14. Memperoleh publisitas atas produk-produk yang tidak boleh diiklankan 15. Memperoleh pemberitaan televisi atas produk-produk yang tabu diiklankan di TV

16. Mengetes konsep pemasaran 17. Mengidentifikasikan produk (merek) dengan nama perusahaan 
18. Mendapatkan dukungan

konsumen dengan menjelaskan misi

perusahaan

19. Mendorong motivasi tenaga-

tenaga penjual (sales force)

20. Memperoleh dukungan dari para penyalur.

\section{Peran Marketing Public Relations (MPR)}

1.Memupuk citra positif perusahaan dan produk di mata konsumen.

2.Melengkapi elemen promosi periklanan suatu produk.

3.Meningkatkan kepercayaan konsumen terhadap pesan-pesan yang disampaikan melalui jalur public relations karena public relations merupakan fungsi manajemen yang menilai sikap publik, mengidentifikasi kebijakan dan tata cara seseorang atau organisasi demi kepentingan publik, serta merencanakan dan melakukan suatu program kegiatan untuk memperoleh pengertian, pemahaman dan dukungan dari publiknya.

\section{Bentuk-bentuk Kegiatan Marketing Public Relations (MPR)}

1. Pemberian berbagai hadiah menarik pada acara tertentu.

2.Pelaksanaan seminar, diskusi bersama, dan open house.

3.Mengadakan program-program ajang khusus untuk meningkatkan citra.

4.Mengadakan program yang bertujuan untuk memupuk rasa sense of belonging konsumen terhadap perusahaan
Sedangkan menurut Scott $M$. Cutlip dan Allen Center dalam Rhenald Kasali (2005), (memberikan penjelasan mengenai konsep fungsional PR sebagai berikut:

1. Memudahkan dan menjamin arus opini yang bersifat mewakili dari public- publik suatu lembaga, sehingga kebijaksanaan beserta operasionalisasi lembaga dapat dipelihara keserasiannya dengan ragam kebutuhan dan pandangan publik-publik tersebut.

2. Menasehati manajemen mengenai jalan dan cara menyusun kebijaksanaan dan operasionalisasi lembaga untuk dapat diterima secara maksimal oleh publik.

3. Merencanakan dan melaksanakan program-program yang dapat menimbulkan penafsiran yang menyenangkan terhadap kebijaksanaan dan operasionalisasi lembaga.

Fungsi humas memfokuskan pada penciptaan dampak yang menyenangkan pada publiknya atas kebijaksanaan dan operasionalisasinya oleh pimpinan lembaga. Tentu saja bagi lembaga, dampak yang diinginkan adalah dampak yang dapat menguatkan citra positifnya dari sudut pandang publik.

Berbeda dengan Cutlip dan Center, Bertnard R. Canfield, dalam bukunya Public Relations: Principles and Problems mengemukakan fungsi PR dari sudut pandang publiknya sendiri, yaitu bagaimana lembaga berusaha untuk mengikuti apa yang diinginkan publik dari lembaga : umum.

1. Mengabdi kepada kepentingan

2. Memelihara komunikasi yang baik. 
3. Menitikberatkan moral dan perilaku yang baik.

Sedangkan fungsi PR menurut Edwin Emery, Philip H. Ault dan Warren K. Agee dalam bukunya Introduction to Mass Commnunication (1991) adalah upaya yang berencana untuk mempengaruhi dan membina opini yang menyenangkan melalui penampilan yang dapat diterima, dilakukan secara jujur, dan dengan kepercayaan melalui dua jalur komunikasi. Ia seharusnya merupakan fungsi 'manajemen' yakni, upaya yang berencana itu harus didasarkan pada pernyataan kebijaksanaan yang mapan dan yang disetujui, yang mencerminkan prinsipprinsip dan kegiatan-kegiatan yang dilakukan oleh lembaga.

\section{d. Citra Perusahaan}

Dalam Kamus Besar Bahasa Indonesia, pengertian citra adalah (1) kata benda: gambar, rupa, gambaran, (2) gambaran yang dimiliki orang banyak mengenai pribadi, perusahaan, organisasi atau produk, (3) kesan mental atau bayangan visual yang ditimbulkan oleh sebuah kata, frase atau kalimat, dan merupakan unsur dasar yang khas dalam karya prosa atau puisi dan (4) data atau informasi dari potret udara untuk bahan evaluasi.

Citra adalah seperangkat ide dan kesan seseorang terhadap suatu obyek tertentu. Sikap dan tindakan seseorang terhadap suatu obyek akan ditentukan oleh citra obyek tersebut yang menampilkan kondisi terbaiknya, (Ruslan, 2003). Suatu perusahaan harus melakukan analisis citra (image analysis) dalam mengetahui sejauhmana peranan PR dalam perusahaan tersebut. Analisis citra tersebut terdiri dari analisis terhadap khalayak sasaran yang memerlukan penilaian (tanggapan), peserta (public) tentang citra perusahaan, citra program, pelayanan jasa, penampilan pemberian pelayanan, dan para pesaingnya.

Sedangkan menurut Power (2005) menyebutkan citra perusahaan adalah citra keseluruhan dari kesatuan dari citra merek produk (product brand image), citra merek perusahaan (corporate brand image) dan citra pemimpin perusahaan. Citra dapat berbentuk positif dan negatif. Citra positif dapat terbentuk apabila publik mendapatkan informasi yang baik mengenai suatu perusahaan dan begitu sebaliknya untuk citra negatif. Ketika berkomunikasi dengan pihak eksternal (khalayak), PR memiliki strategi khusus dalam mencapai pembentukan citra positif sebagai sasaran perusahaan. PR dapat melakukan teleconference maupun press release atau menggunakan media. Masing-masing memiliki kelebihan dan kekurangan tersendiri.

Hamidi (2007) menyebutkan komunikasi dapat dikatakan efektif bila pesan yang disampaikan dapat dipahami oleh komunikan, komunikan bersikap atau berperilaku seperti apa yang dikehendaki komunikator dan ada kesesuaian antar-komponen. Asumsi dalam teori tentang efektivitas pesan yaitu jika komunikasi diharapkan efektif maka pesan-pesannya perlu dikemas sedemikian rupa sehingga sesuai atau merupakan kebutuhan komunikan, menarik perhatian, simbol yang mudah dipahami dan cara memperoleh yang mudah. Apabila PR memperhatikan hal tersebut maka bukan tidak mungkin citra positif perusahaan akan terbentuk di benak 
publik sasaran atau dengan kata lain strategi pencitraan dapat efektif.

Katz dalam Soemirat dan Ardianto (2004) mengatakan bahwa citra adalah cara bagaimana pihak lain memandang sebuah perusahaan, seseorang, suatu komite, atau suatu aktivitas. Setiap perusahaan mempunyai citra. Setiap perusahaan mempunyai citra sebanyak jumlah orang yang memandangnya. Berbagai citra perusahaan datang dari pelanggan perusahaan, pelanggan potensial, bankir, staf perusahaan, pesaing, distributor, pemasok, asosiasi dagang, dan gerakan pelanggan di sektor perdagangan yang mempunyai pandangan terhadap perusahaan.

Jefkins (2004) menyebutkan beberapa jenis citra (image). Berikut ini lima jenis citra yang dikemukakan, yakni:

1. Citra bayangan (mirror image). Citra ini melekat pada orang dalam atau anggota-anggota organisasi biasanya adalah pemimpinnya- mengenai anggapan pihak luar tentang organisasinya.

2. Citra yang berlaku (current image). Adalah suatu citra atau pandangan yang dianut oleh pihak-pihak luar mengenai suatu organisasi.

3. Citra yang diharapkan (wish image). Adalah suatu citra yang diinginkan oleh pihak manajemen.

4. Citra perusahaan (corporate image). Adalah citra dari suatu organisasi secara keseluruhan, jadi bukan sekedar citra atas produk dan pelayanannya.

5. Citra majemuk (multiple image). Banyaknya jumlah pegawai (individu), cabang, atau perwakilan dari sebuah perusahaan atau organisasi dapat memunculkan suatu citra yang belum tentu sama dengan organisasi atau perusahaan tersebut secara keseluruhan.

Soemirat dan Ardianto (2004) menjelaskan efek kognitif dari komunikasi sangat mempengaruhi proses pembentukan citra seseorang. Citra terbentuk berdasarkan pengetahuan dan informasi-informasi yang diterima seseorang.

\section{PENUTUP}

\section{a. Kesimpulan}

Komunikasi tidak secara langsung menimbulkan perilaku tertentu, tetapi cenderung mempengaruhi cara kita mengorganisasikan citra kita tentang lingkungan. Public Relations digambarkan sebagai input-output, proses intern dalam model ini adalah pembentukan citra, sedangkan input adalah stimulus yang diberikan dan output adalah tanggapan atau perilaku tertentu.

Perbedaan Corporate Public Relations (CPR) yang sering disebut dengan Public Relations (PR) dengan advertising adalah bahwa kegiatan advertising secara relatif membutuhkan waktu yang lebih pendek dan dapat segera diukur hasilnya sedang kegiatan public relations membutuhkan waktu yang lebih lama, karena menyangkut mengubah persepsi orang. Dalam hal anggaran biaya, Marketing Public Relations (MPR) sangatlah efisien dan dalam pencapaian hasilnya pun sangatlah efektif. 
Marketing Public Relations dan Advertensi keduanya merupakan alat-alat yang dapat digunakan oleh perusahaan sebagai unsur dari promotional mix. Tujuan dari pelaksanaan public relations tidak hanya sekedar untuk meningkatkan penjualan semata tetapi lebih jauh dari itu yakni berusaha memberikan gambaran yang utuh tentang produk maupun corporate kepada stakeholder-nya, sehingga mampu memberikan image yang positif mengenai produk maupun perusahaan.

\section{b. Saran}

Efektivitas CPR di dalam pembentukan citra (nyata, cermin dan aneka ragam) organisasi, erat kaitannya dengan kemampuan (tingkat dasar dan lanjut) pemimpin dalam menyelesaikan tugas organisasinya, baik secara individual maupun tim yang dipengaruhi oleh praktek berorganisasi (job design, reward system, komunikasi dan pengambilan keputusan) dan manajemen waktu/ perubahan dalam mengelola sumberdaya (materi, modal dan SDM) untuk mencapai tujuan yang efisien dan efektif, yaitu mencakup penyampaian perintah, informasi, berita dan laporan, serta menjalin hubungan dengan orang. Hal ini tentunya erat dengan penguasaan identitas diri yang mencakup aspek fisik, personil, kultur, hubungan organisasi dengan pihak pengguna, respons dan mentalitas pengguna.

Praktisi PR senantiasa dihadapkan pada tantangan dan harus menangani berbagai macam fakta yang sebenarnya, terlepas dari apakah fakta itu hitam, putih, atau abu-abu. Perkembangan komunikasi tidak memungkinkan lagi bagi suatu organisasi untuk menutup-nutupi suatu fakta. Citra PR yang ideal adalah kesan yang benar, yakni sepenuhnya berdasarkan pengalaman, pengetahuan, serta pemahaman atas kenyataan yang sesungguhnya. Itu berarti citra tidak seharusnya "dipoles agar lebih indah dari warna aslinya", karena hal itu justru dapat merusak maknanya.

\section{Referensi}

Agee, Warren K., Phillip H. Ault, and Edwin Emery, 1991. Introduction to Mass Communications, New York: HarperCollins Publishers Inc.

Cutlip, Scoot M, Allen H. Center, and Glen M. Broom. 1985. Effective Public Relations. $6^{\text {th }}$ Edition. Englewood Cliffs. Prentice Hall. New Jersey. EBook (Online), diakses 18 November 2014.

Duncan, Tom. 2004. IMC: Using Advertising \& Promotion to Build Brand. First Edition. McGraw-Hill, Inc.

Advertising \& IMC. Second Edition. McGraw-Hill, Inc. USA.

Grunig, James E. 1989. Journal: "Public, Audience and Market Segments": Models of Receivers of Campaign Messages".,CT. Salmon (Ed), Informations Campaigns: Managing The Process of Social hanges. Newbury Park. California. (Online), diakses 10 November 2014.

Idris, Abdul Rasyid. 2005. Corporate Social Responsibility (CSR) Sebuah Gagasan 
dan Implementasi. Dokumen

http://www.fajar.co.id/, (Online), diakses 18 November 2014.

Jefkins, Frank. 2004. Public Relations. Terjemahan Daniel Yadin. Edisi Kelima. Penerbit Erlanggan. Jakarta.

Kotler. Philiph. 2003. Marketing Management, Eleventh edition, Prentice Hall International. USA.

Linggar, Anggoro. 2002. Teori dan Profesi Kehumasa Serta Aplikasinya di Indonesia. Cetakan Ketiga. Bumi Aksara, Jakarta

Ruslan, Rosady. 2005. Kampanye Public Relations. PT.Raja Grafindo Persada. Jakarta.

--.-. 2008. Manajemen Public Relations \& Media Komunikasi. PT. Raja Grafindo Persada. Jakarta.

Rhenald. Kasali. 2005. Manajemen Public Relations Konsep Dan Aplikasinya. Grafiti. Jakarta.

Widjaja. 2008. Komunikasi dan Hubungan Masyarakat. PT.Bumi Aksara. Jakarta. 
Jurnal Al-Iqtishad, Edisi 11 Volume II Tahun 2015 